\title{
Effectiveness of E-Training, E-Leadership, and Work Life Balance on Employee Performance during COVID-19
}

\author{
Christian Wiradendi WOLOR ${ }^{1}$, Solikhah SOLIKHAH ${ }^{2}$, Nadya Fadillah FIDHYALLAH ${ }^{3}$, \\ Deniar Puji LESTARI ${ }^{4}$
}

Received: July 03, 2020 Revised: August 23, 2020 Accepted: August 28, 2020

\begin{abstract}
This study aims to add insight into the effectiveness of e-training, e-leadership, work-life balance, and work motivation on millennial generation employees' performance in today's work life amid the outbreak of the COVID-19 pandemic that requires to work more online. Unlike previous generations, millennials are technology-literate, intent on succeeding quickly, give up easily, and seek instantaneous gratification. The population in this study are millennial generation employees at one of Honda motorcycle dealers in Jakarta, Indonesia. The number of samples collected was 200. The sampling technique used is the side probability method, with proportional random sampling technique. The research method used is an associative quantitative approach through survey methods and Structural Equation Modeling. Data were collected through questionnaires distributed to millennial generation employees, with results then processed through the Lisrel 8.5 program. The results of this study show, first, that e-training, e-leadership, and work-life balance have positive effect on work motivation. Second, e-training, e-leadership, work-life balance, and work motivation have positive effect on employees' performance. The findings indicate that companies must pay attention to the factors of e-training, e-leadership, and work-life balance to keep employees motivated and to maintain optimal employee performance, especially during the COVID-19 pandemic through working online.
\end{abstract}

Keywords: E-Training, E-Leadership, Work-Life Balance, Work Motivation, Employee Performance

JEL Classification Code: J81, L10, M53, M54, O15

\section{Introduction}

Initially known as coronavirus, the COVID-19 has become a pandemic spread throughout the world. This led to the isolation of many regions and has a very drastic impact on the economy (Bayuni, 2020). This makes people work more online to keep themselves productive and maintain their performance amid the outbreak (Fachriansyah, 2020).

${ }^{1}$ First Author and Corresponding Author, Lecturer, Faculty of Economics, Universitas Negeri Jakarta, Indonesia [Postal Address: Rawamangun Muka Street, Rawamangun, Jakarta, 13220, Indonesia]. Email: christianwiradendi@unj.ac.id

${ }^{2}$ Lecturer, Faculty of Economics, Universitas Negeri Jakarta, Indonesia

${ }^{3}$ Lecturer, Faculty of Economics, Universitas Negeri Jakarta, Indonesia

${ }^{4}$ Faculty of Economics, Universitas Negeri Jakarta, Indonesia

(c) Copyright: The Author(s)

This is an Open Access article distributed under the terms of the Creative Commons Attribution Non-Commercial License (https://creativecommons.org/licenses/by-nc/4.0/) which permits unrestricted non-commercial use, distribution, and reproduction in any medium, provided the original work is properly cited.
The tight competition between companies in the era of the global economy adds to the challenges of always be at the forefront and be the best in providing satisfying services to consumers. Employees are encouraged to perform well and contribute to the progress of the company. When looking at current developments, companies are hiring employees belonging to the millennial generation born in the 19802000s. Millennials are characterized as technology-literate, intent on succeeding quickly, giving up easily, and looking for instantaneous gratification. This is certainly different from previous generations and is one of the new challenges for the world of work (Pyöriä, Ojala, Saari, \& Järvinen, 2017).

The COVID-19 pandemic increasingly triggers an intense competition between companies challenged to achieve optimal performance for the millennial generation. There are several aspects to this research related to the improvement of millennial generation performance during this pandemic period. The first aspect is e-training where in recent years the use of the Internet has greatly influenced the lives of many people, especially in training. This has contributed very substantially to the emergence of electronic training, 
bearing in mind that traditional training has constraints and limitations that reduce its effectiveness on the international level given the changes that occur globally. E-training is an effective input for the development of human resources, especially the millennial generation and the formation of cadres who are able to achieve goals in the organization (Hila, Alhelou, Shobaki, \& Naser, 2017).

The second aspect is e-leadership. The millennial generation has more difficulty to be loyal and committed to the industry because its keywords are freedom, flexibility, dialogue, open communication with superiors and colleagues, and the use of technology. Companies must now pay attention and think about the importance of changing and adapting the manager's leadership strategy toward its staff, which on average is being made up of millennials (Mansor, Mun, Farhana, \& Tarmiz, 2017; Putriastuti \& Stasi, 2019; Valenti, 2019).

The third aspect is about work-life balance. Work-life balance is a crucial issue for every employee, especially for millennial-generation employees. This is because there will be a decrease in employee productivity and performance if an organization does not think about the work balance of employees properly and is not well managed (Abioro, Oladejo, \& Ashogbon, 2018). Work balance programs began in 1930 where company policies and regulations allow employees to work effectively and efficiently and provide flexible time to deal with their personal problems. The fact is, at present, the workforce places more emphasis on work-life balance than on income alone (Meenakshi, V, \& Ravichandran, 2013; Chaitra, Kumar, \& Murthy, 2015).

The fourth aspect that can improve performance is work motivation. Motivation is a process that drives a person to achieve organizational goals with maximum work results (Pancasila, Haryono, \& Sulistyo, 2020). There is a strong relationship between motivation, action or behavior needs, goals, and satisfaction as well as performance. In previous studies, the results show that work motivation has a significant effect on performance (Nguyen et al., 2020). The purpose of this study is to add insight into assessing the effectiveness of e-training, e-leadership, work-life balance, and work motivation on millennial generation employees' performance in today's work-life amid the outbreak of the COVID-19 that requires to work more online using quantitative methodology to support this research. Then, we present the results of our empirical analysis and discuss its implications.

\section{Literature Review}

\subsection{Employee Performance}

Performance is one of the benchmarks used to determine whether a job is done well or not. Employee performance is the result of work related to success and failure in an organization (Sopiah, Kurniawan, Nora, \& Narmaditya, 2020). Performance is an important mechanism for management to explain the goals and performance standards, to motivate individual performance in the future for the sake of organizational sustainability (Shafini et al., 2016). Employee performance, according to Mangkunegara (2015), has four indicators, namely, Quality, Quantity, Reliability in the Implementation of tasks, and Attitude.

\subsection{Millennial Generation}

Millennials were born between 1980 and 2000 (Murphy, Gibson, \& Greenwood, 2010; Schultz, Schwepker, \& Good, 2012). Millennium is a generation of young people characterized by the use and adaptation of technology in their daily lives, as well as values, life experiences, motivation, and general buying behavior (Smith \& Nichols, 2015; Yigit $\&$ Aksay, 2015). This generation is a group of consumers and residents of the world who have been labeled as Generation Y, Millennial, and Echo Boom (Moreno, Lafuente, Carreón, \& Moreno, 2017).

\subsection{E-Training}

E-training resembles e-learning in many ways especially in terms of the delivery method and technology used, except that it refers to a much shorter learning timeframe usually designed specifically to achieve a particular learning goal or skill (Ramayah, Ahmad, \& Hong, 2012). E-training is defined as a process of distance training through the use of the Internet or Intranet, giving individuals the required knowledge about various subjects chosen (Amara \& Atia, 2016).

\subsection{E-Leadership}

The era of digitalization created a revolution in the industrial world that shaped the reconstruction of the concept of leadership, which was labeled as e-leadership as a result of the development of information technology (Mohammad, 2009). E-leadership theory studies leadership in work environments that support technology that has an impact on potential interactions and electronic communication networks (Putriastuti \& Stasi, 2019). E-leadership achieves the same goals as traditional leadership through information technology (Iriqat \& Khalaf, 2017). E-leadership has roles and responsibilities where leaders can communicate with their employees even though they are not in the same office, and they must understand new technology to meet employee needs and build relationships between employees (Mohammad, 2009). 


\subsection{Work-Life Balance}

Work-life balance is said to be the balance of the time someone spends working compared to the time spent on one's personal life (Abioro et al., 2018; Lazar, Osoian, \& Ratiu, 2010). Work-life balance is also how to create a healthy and supportive work environment, which allows employees to have a balance between work and personal responsibility and thereby improve employee performance (Delecta, 2011; Dhas, 2015). Work-life balance is supported by two concepts, namely, achievement, and happiness (W. Wolor, Kurnianti, Zahra, \& Martono, 2020). Someone must have both, this is the reason why those who are considered successful do not feel as happy or unhappy as they should be (Bataineh, 2019).

\subsection{Work Motivation}

Motivation is all forms of hope, desire, and drive to work (Oren, Tziner, Nahshon, \& Sharoni, 2013). Work motivation also focuses attention on personality characteristics, individual dispositions, and the influence of external factors on the behavior of individual learners to achieve organizational goals (John, Francis, \& Chukwu, 2012). Motivation factors have a direct relationship with performance, and employees who have high motivation can deliver high performance as well. The results of his research also showed that work motivation affects employee performance (John et al., 2012; Pancasila et al., 2020; Siagian, 2014).
Research Hypothesis:

H1: E-Training influences Employee Performance

H2: E-Training affects Work Motivation

H3: E-Leadership influences Employee Performance

H4: E-Leadership influences Work Motivation

H5: Work-Life Balance affects Employee Performance

H6: Work-Life Balance affects Work Motivation

H7: Work Motivation influences Employee Performance

\section{Method}

The research method used in this study is the Structural Equation Modeling (SEM) method. Structural Equation Modeling is a second-generation multivariate analysis technique that combines factor analysis and path analysis to enable researchers to test and estimate the relationship between multiple exogenous and multiple endogenous variables simultaneously with many indicators (Hengky Latan, 2012). The population in this study is millennial generation employees at one of Honda motorcycle dealers in Jakarta, Indonesia. The total population of motorcycle salespeople in Bekasi is 302. The sampling technique that researchers use is the side probability method, with a proportional random sampling technique. In this study, the number of samples taken was 200. This refers to the sample size used in research with SEM analysis published in the psychology journal and management science using this sample size (Yamin, 2014).

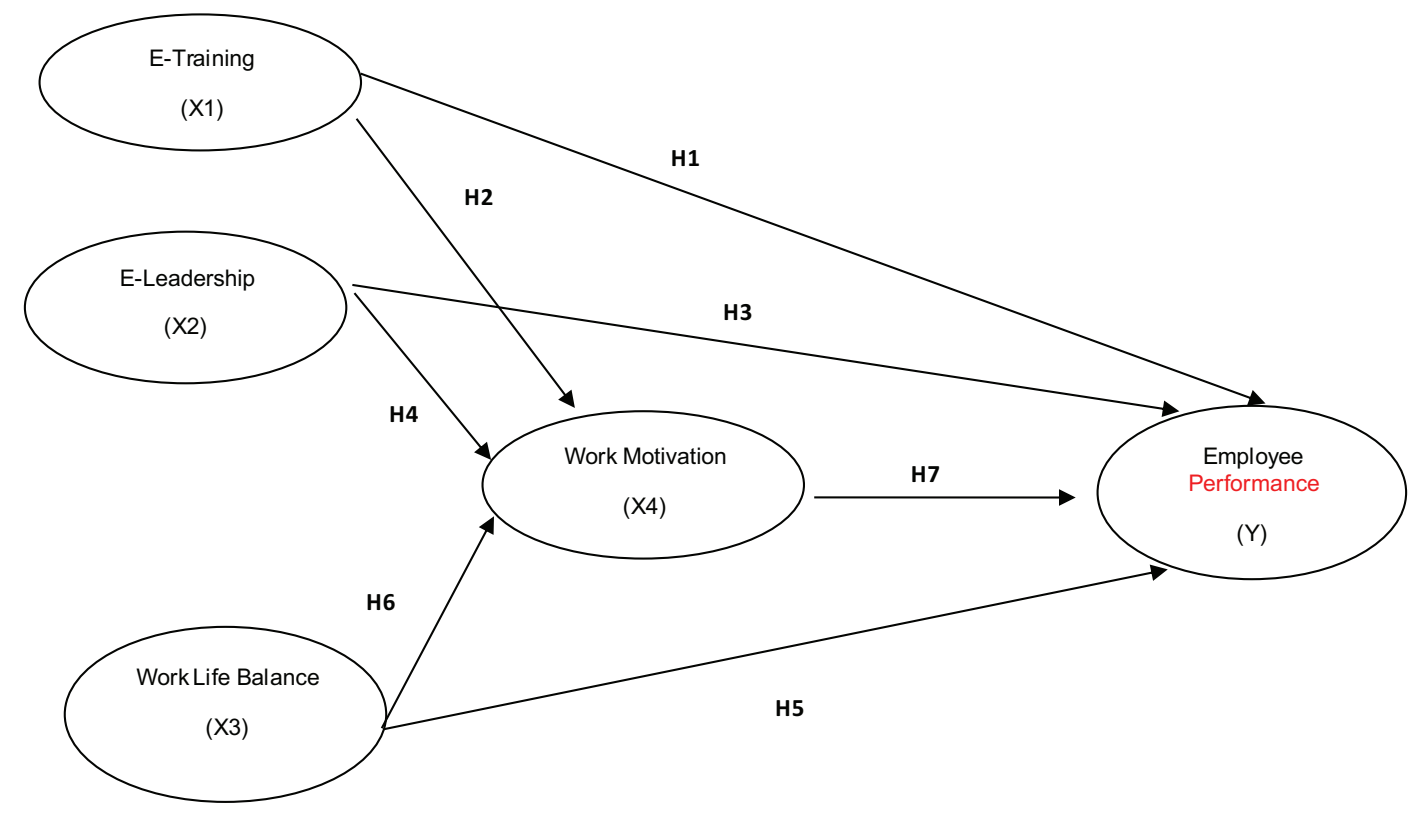

Figure 1: Research Model 


\subsection{Results and Discussion}

Goodness of fit is an indication of the comparison of the model specified with the covariance matrix between indicators or observed variables. If the goodness of fit produced by a model is bad, then the model must be rejected. This method is to estimate the initial measurement model (CFA) and simultaneously evaluate the measurement model. Table 1 shows that GOF size consists of three measures, namely, absolute (absolute fit test), parsimonious (parsimonious fit measures), and comparative (incremental fit measures) measures. A large Chi-square value and a value of $p=(1.00>0.05)$ means that the model fits well because what is desired is a small Chi-square value and $p>0.05$. This shows that the model has a good fit. A good ECVI model value must be smaller than ECVI Saturated and ECVI Independence. ECVI in the above table is 8.93, smaller than ECVI Saturated, which is 16.61, and ECVI Independence, which is 61.75. This shows that the model has a good fit. The recommended CFI value for a good model indication is $>$ 0.9 . Value $0.8 \leq \mathrm{CFI} \leq 0.9$ is marginal fit (good enough). In the table, the CFI value is equal to 1.00 . This shows that the model has a good fit.

\section{Results and Discussion}

Structural model analysis produces estimated values of causal relationships between standardized variables, while testing hypotheses is done by looking at t-values.

Where:

\section{ET : E-Training \\ 2. EL: E-Leadership \\ 3. WLB : Work-Life Balance \\ 4. WM : Work Motivation \\ 5. EP: Employee Performance}

Structural model analysis results, shown in Figures 2 and 3 , produce estimates of causal relationships between standardized variables in the form of t-value and standardized solution values. Figures 2 and 3 also illustrate the effect of each variable. The explanation is described as follows:

The effect of e-training on employee performance is positive $(0.21)$ and significant $(2.75>1.96)$. Thus, it can be said that e-training has a direct positive effect on employee performance. The results of this study reinforce the research conducted by Kamal where the main purpose of e-training is to improve employee performance and the level of satisfaction felt by employees to create a productive workforce (Kamal, Aghbari, \& Atteia, 2016). E-training is a human resource management activity to improve employee performance (Hila et al., 2017). E-training can be beneficial for improving employee performance because employees can access training resources through the Internet all over the world (Christian, Krieger, Holzinger, \& Behringer, 2007).

The effect of e-training on work motivation is positive $(0.19)$ and significant $(2.37>1.96)$. Thus, it can be said that e-training has a direct positive effect on work motivation. The results of this study reinforce the research conducted by Hila in which e-training can increase the work motivation of employees (Hila et al., 2017) and encourage participation in activities in the company (Razak, Yusop, Perumal, \& Chukumaran, 2015). Kabbasi's research states that e-training can stimulate motivation and improve employee performance. She added that digital literacy and media sophistication are needed to succeed in every aspect of life even at work (Kabassi \& Virvou, 2004).

The influence of e-leadership on employee performance is positive $(0.21)$ and significant $(2.71>1.96)$. Thus, it can be said that e-leadership has a direct positive effect on employee performance. The results of this study reinforce the research conducted by Avolio in which e-leadership is a combination of leadership context and technology contributing to and optimizing employee performance (Avolio, Kahai, \& Dodge, 2001). Hema and Gupta added that e-leadership is a new paradigm that provides a variety of new opportunities, namely, the ability to communicate directly one-on-one with employees, customers, and suppliers using technology to improve performance (Hema \& Gupta, 2015). E-leadership adapts and integrates virtuality to ensure the success and performance of its employees (Darics, 2020; Fernandez \& Jawadi, 2015).

The influence of e-leadership on work motivation is positive $(0.20)$ and significant $(2.25>1.96)$. Thus, it can be said that e-leadership has a direct positive effect on work motivation. The results of this study reinforce the research conducted by Hema and Gupta who said that the structure of

Table 1: Goodness of Fit Statistics

\begin{tabular}{|l|l|c|c|c|}
\hline No & \multicolumn{1}{|c|}{ Goodness of Fit } & Cut-Off Value & Tabel & Ket \\
\hline 1 & Chi-square & $p>0.05$ & 1.00 & Good Fit \\
\hline 2 & $\begin{array}{l}\text { Expected cross-validation index } \\
(\mathrm{ECVI})\end{array}$ & $\begin{array}{l}<\text { ECVI Saturated dan } \\
\text { Independence Model }\end{array}$ & $\begin{array}{c}\text { ECVI Sat }=8.93<16.61 ; \\
\text { ECVI Ind }=61.75\end{array}$ & Good Fit \\
\hline 3 & Comparative Fit Index (CFI) & $>0.9$ & 1.00 & Good Fit \\
\hline
\end{tabular}




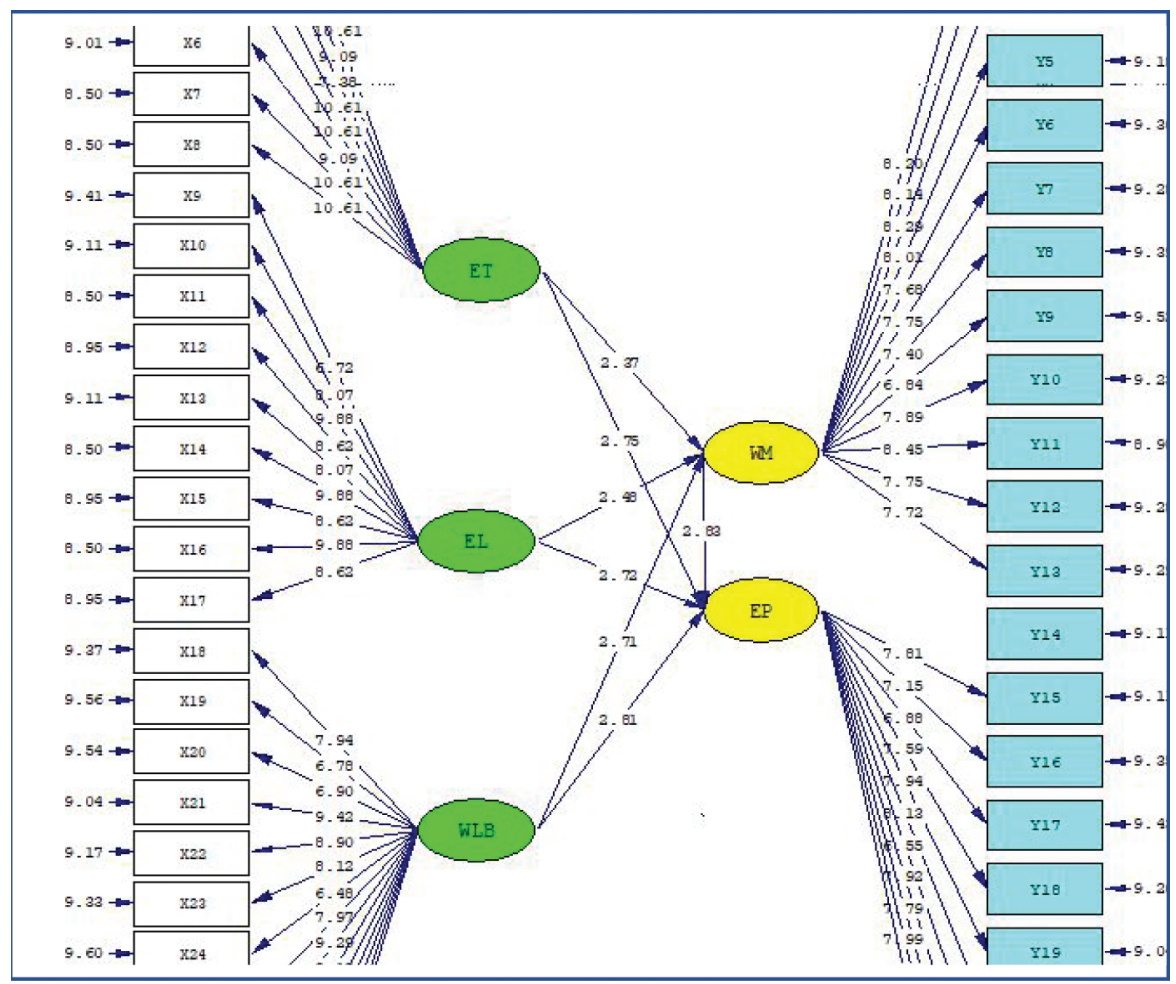

Figure 2: Structural Model (t-value)

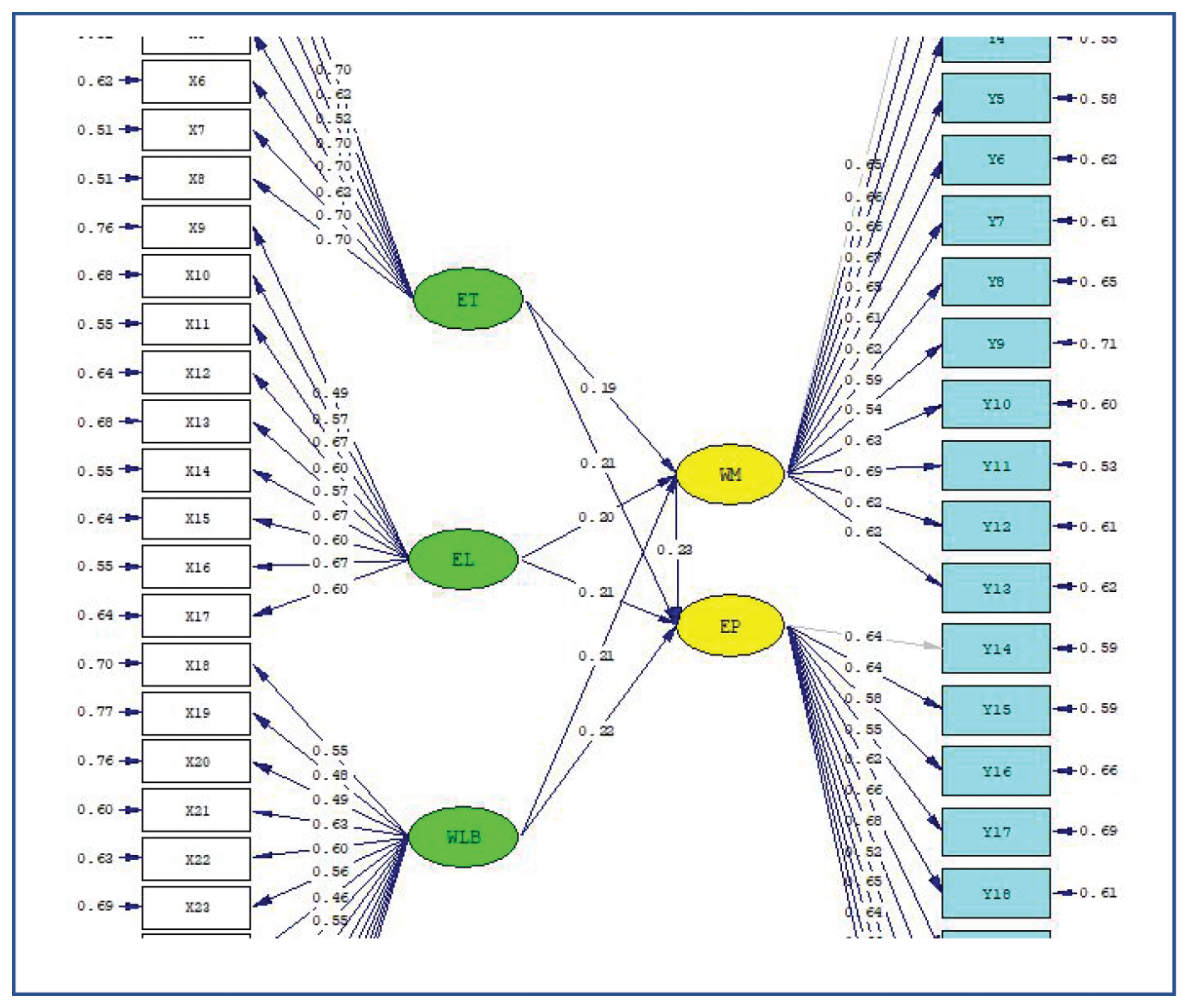

Figure 3: Structural Model (Standardized Solution) 
Table 2: Causal Relations between Variables

\begin{tabular}{|c|c|c|c|c|c|c|}
\hline No & Path & $\begin{array}{l}\text { Standardization } \\
\text { Coefficient }\end{array}$ & t-value & t-table & Significance & Conclusion \\
\hline 1 & $\begin{array}{l}\text { E-Training } \rightarrow \\
\text { Employee Performance }\end{array}$ & 0.21 & 2.75 & 1.96 & Significance & $\begin{array}{l}\text { There is sufficient evidence that } \\
\text { e-training has a positive effect on } \\
\text { employee performance }\end{array}$ \\
\hline 2 & $\begin{array}{l}\text { E-Training } \rightarrow \\
\text { Work Motivation }\end{array}$ & 0.19 & 2.37 & 1.96 & Significance & $\begin{array}{l}\text { There is enough evidence that } \\
\text { e-training has a positive effect on } \\
\text { work motivation }\end{array}$ \\
\hline 3 & $\begin{array}{l}\text { E-Leadership } \rightarrow \\
\text { Employee Performance }\end{array}$ & 0.21 & 2.71 & 1.96 & Significance & $\begin{array}{l}\text { There is sufficient evidence that } \\
\text { e-leadership has a positive effect on } \\
\text { employee performance }\end{array}$ \\
\hline 4 & $\begin{array}{l}\text { E-Leadership } \rightarrow \\
\text { Work Motivation }\end{array}$ & 0.20 & 2.25 & 1.96 & Significance & $\begin{array}{l}\text { There is enough evidence that } \\
\text { e-leadership has a positive effect on } \\
\text { work motivation }\end{array}$ \\
\hline 5 & $\begin{array}{l}\text { Work Life Balance } \rightarrow \\
\text { Employee Performance }\end{array}$ & 0.22 & 2.81 & 1.96 & Significance & $\begin{array}{l}\text { There is sufficient evidence that } \\
\text { work-life balance has a positive effect } \\
\text { on employee performance }\end{array}$ \\
\hline 6 & $\begin{array}{l}\text { Work Life Balance } \rightarrow \\
\text { Work Motivation }\end{array}$ & 0.21 & 2.71 & 1.96 & Significance & $\begin{array}{l}\text { There is enough evidence that work- } \\
\text { life balance has a positive effect on } \\
\text { work motivation }\end{array}$ \\
\hline 7 & $\begin{array}{l}\text { Work Motivation } \rightarrow \\
\text { Employee Performance }\end{array}$ & 0.23 & 2.83 & 1.96 & Significance & $\begin{array}{l}\text { There is enough evidence that work } \\
\text { motivation has a positive effect on } \\
\text { employee performance }\end{array}$ \\
\hline
\end{tabular}

technology influences leadership styles that affect employee motivation and performance (Hema \& Gupta, 2015). In his research, Gupta added that e-leadership is needed to increase the motivation to work from its employees such as challenges faced in the form of confusion, language barriers, cultural differences, and technological disruption (Hema \& Gupta, 2015). Belitski states that a leader and technology make it easier to monitor and motivate employees (Belitski \& Liversage, 2019).

The effect of work-life balance on employee performance is positive $(0.22)$ and significant $(2.81>1.96)$. Thus, it can be said that work-life balance has a direct positive effect on employee performance. The results of this study strengthen Aryee's research where control over work and family roles can improve performance, which leads to job satisfaction (Aryee, Tan, \& Srinivas, 2005). Dash said the negative effects when employees work excessively, namely, high absenteeism, decreased productivity, and decreased performance (Darko-Asumadu, Sika-Bright, \& Osei-Tutu, 2018; Dhas, 2015). Employee work-life balance helps in reducing stress levels at work and increasing employee performance (R et al., 2015). Darcy's research states that work and life balance can affect the level of employee performance in the organization (Darcy, Mccarthy, Hill, \& Grady, 2012).
The effect of work-life balance on work motivation is positive $(0.21)$ and significant $(2.71>1.96)$. Thus, it can be said that work-life balance has a direct positive effect on work motivation. This strengthens the research of Aryee that the existence of a balance of life and work can increase motivation, but if there is excess in the portion of work it will negatively affect employee motivation. If there is no balance of work and personal life, it will cause conflicts with the family (Aryee et al., 2005). Chaitra in his research said that companies that offer work programs such as flexible hours, vacation programs, child care centers, health care centers, etc. will motivate employees to work efficiently ( $\mathrm{R}$ et al., 2015).

The effect of work motivation on employee performance is positive $(0.23)$ and significant $(2.83>1.96)$. Thus, it can be said that work motivation has a direct positive effect on employee performance. The results of this study reinforce the theory that the right motivation for employees will have an impact on the employee's performance (Oren et al., 2013). The results of this study are also consistent with research conducted by Pancasila who said that motivation is closely related to the emergence of a tendency to work and perform well to achieve goals (Pancasila et al., 2020). John's research results also show that work motivation affects employee performance (John et al., 2012). 


\section{Conclusion}

After testing the hypotheses, the conclusions point to the fact that e-training, e-leadership, work-life balance, and work motivation have a positive and significant impact on employee performance. This study also has practical implications for companies during the COVID-19 period: it was important to implement strategic steps related to technology and life balance and work in supporting the improvement of employee motivation and performance.

\section{References}

Abioro, M. A., Oladejo, D. A., \& Ashogbon, F. O. (2018). Work Life Balance Practices And Employees Productivity In The Nigerian University System. Crawford Journal Of Business \& Social Sciences, 8(2), 49-59.

Amara, N. B., \& Atia, L. (2016). E-Training And Its Role In Human Resources Development. Global Journal of Human Resource Management, 4(1), 1-12.

Aryee, S., Tan, H. H., \& Srinivas, E. S. (2005). Rhythms of Life : Antecedents and Outcomes of Work - Family Balance in Employed Parents. Journal of Applied Psychology, 90(1), 132146. https://doi.org/10.1037/0021-9010.90.1.132

Avolio, B. J., Kahai, S., \& Dodge, G. E. (2001). E-Leadership : Implications For Theory, Research, And Practice. Leadership Quarterly, 11(4), 615-668.

Bataineh, K. A. (2019). Impact of Work-Life Balance, Happiness at Work , on Employee Performance. International Business Research, 12(2). https://doi.org/10.5539/ibr.v12n2p99

Bayuni, E. (2020, March 17). COVID-19 lockdown? It's not the economy. It's people's health and lives! The Jakarta Post. Retrieved from https://www.thejakartapost.com/ academia/2020/03/17/covid-19-lockdown-its-not-theeconomy-stupid-its-peoples-health-and-lives.html

Belitski, M., \& Liversage, B. (2019). E-Leadership in Small and Medium-Sized Enterprises in the Developing World. Technology Innovation Management Review, 9(1), 64-75.

Chaitra, Kumar, A., \& Murthy, R. (2015). A Study on Work Life Balance of the Employees at Bosch Ltd, Bangalore. BIMS International Journal of Social Science Research, 1(2), 61-68. http://www.informaticsjournals.com/index.php/bims/article/ view/16233

Christian, J., Krieger, H., Holzinger, A., \& Behringer, R. (2007). Virtual and Mixed Reality Interfaces for e-Training : Examples of Applications in Light Aircraft Maintenance. In: 12th International Conference Human-Computer Interaction (HCI) International. Beijing, China.

Darcy, C., Mccarthy, A., Hill, J., \& Grady, G. (2012). Work - life balance: One size fits all? An exploratory analysis of the differential effects of career stage. European Management Journal, 30(2), 111-120. https://doi.org/10.1016/j.emj.2011.11.001
Darics, E. (2020). E-Leadership or " How to Be Boss in Instant Messaging?" The Role of Nonverbal Communication. International Journal of Business Communication, 57(1). https://doi.org/10.1177/2329488416685068

Darko-Asumadu, D. A., Sika-Bright, S., \& Osei-Tutu, B. (2018). The Influence of Work-Life Balance on Employees' Commitment among Bankers in Accra, Ghana. African Journal of Social Work, 8(1), 47-55.

Delecta, P. (2011). Work Life Balance. International Journal of Current Research, 3(4). [Indonesian]

Dhas, B. (2015). A Report on the Importance of Work-Life Balance. International Journal of Applied Engineering Research, 10(9). [Indonesian]

Fachriansyah, R. (2020, March 15). Work-from-home policy in effect at major Jakarta companies over virus concerns. The Jakarta Post. Retrieved from https://www.thejakartapost.com/ news/2020/03/15/work-from-home-policy-in-effect-at-majorjakarta-companies-over-virus-concerns.html

Fernandez, D. B., \& Jawadi, N. (2015). Virtual R\&D Project Teams: From E-Leadership To Performance. The Journal of Applied Business Research, 31(5), 1693-1708.

Hema, G., \& Gupta, S. M. (2015). Adversity Quotient for Prospective Higher Education. The International Journal of Indian Psychology, 2(3). [Indonesian]

Hengky Latan. (2012). Structural Equation Modeling. Bandung, Indonesia: Alfabeta.

Hila, A. A. A., Alhelou, E. M. S., Shobaki, M. M. A., \& Naser, S. S. A. (2017). The Impact of Applying the Dimensions of IT Governance in Improving e-training -Case Study of the Ministry of Telecommunications and Information Technology in Gaza Governorates. International Journal of Engineering and Information Systems, 1(8). [Indonesian]

Iriqat, R. A. M., \& Khalaf, D. M. S. (2017). Using E-Leadership as a Strategic Tool in Enhancing Organizational Commitment of Virtual Teams in Foreign Commercial Banks in North West Bank -Palestine. International Journal of Business Administration, 8(7), 25-32. https://doi.org/10.5430/ijba.v8n7p25

John, A. G., Francis, A. I., \& Chukwu, I. I. (2012). Improving Sales Performance through Sales Force Motivation Strategies: A Study of Pharmaceutical Firms in Nigeria. International Journal of Business and Economics Research, 3(5), 1-15.

Kabassi, K., \& Virvou, M. (2004). Personalised adult e-training on computer use based on multiple attribute decision making. Interacting with Computers, 16, 115-132. https://doi. org/10.1016/j.intcom.2003.11.006

Kamal, K. B., Aghbari, M. A., \& Atteia, M. (2016). E-Training \& Employees 'Performance a Practical Study on the Ministry of Education in the Kingdom of Bahrain. Journal of Resources Development and Management, 18, 1-8.

Lazar, I., Osoian, C., \& Ratiu, P. (2010). The Role of WorkLife Balance Practices in Order to Improve Organizational Performance. European Research Studies, 13(1), 201-214. 
Mangkunegara, A. A. A. P. (2015). Human Resources Management. Remaja Rosdakarya. https://doi.org/10.1038/cddis.2011.1

Mansor, Z. D., Mun, C. P., Farhana, B. S. N., \& Tarmiz, W. A. N. W. M. (2017). Influence of Transformation Leadership Style on Employee Engagement among Generation Y. International Journal of Social, Behavioral, Educational, Economic, Business and Industrial Engineering, 11(1), 161-165.

Meenakshi, S. P., Subrahmanyam, V., \& Ravichandran, K. (2013). The Importance of Work -Life- Balance. IOSR Journal of Business and Management, 14(3), 31-35. http://www. iosrjournals.org/iosr-jbm/papers/Vol14-issue3/F01433135.pdf

Mohammad, K. (2009). E-Leadership: The Emerging New Leadership for the Virtual Organization. Journal of Managerial Sciences, 3(1), 1-21.

Moreno, F. M., Lafuente, J. G., Carreón, F. Á., \& Moreno, S. M. (2017). The Characterization of the Millennials and Their Buying Behavior. International Journal of Marketing Studies, 9(5), 135-144. https://doi.org/10.5539/ijms.v9n5p135

Murphy, E. F., Gibson, J. W., \& Greenwood, R. (2010). Analyzing generational values among managers and non-managers for sustainable organizational effectiveness. SAM Advanced Management Journal, 75(1), 33-43.

Nguyen, H. N., Le, Q. H., Tran, Q. B., Tran, T. H. M., Nguyen, T. H. Y., \& Nguyen, T. T. Q. (2020). The Impact of Organizational Commitment on Employee Motivation : A Study in Vietnamese Enterprises. Journal of Asian Finance, Economics and Business, 7(6), 439-447. https://doi.org/10.13106/jafeb.2020.vol7.no6.439

Oren, L., Tziner, A., Nahshon, Y., \& Sharoni, G. (2013). Relations between ocbs, organizational justice, work motivation and selfefficacy. Amfiteatru Economic, 15(34), 505-516. https://doi. org/10.1016/j.pestbp.2011.02.012.Investigations

Pancasila, I., Haryono, S., \& Sulistyo, B. A. (2020). Effects of Work Motivation and Leadership toward Work Satisfaction and Employee Performance : Evidence from Indonesia. Journal of Asian Finance, Economics and Business, 7(6), 387-397. https:// doi.org/10.13106/jafeb.2020.vol7.no6.387

Putriastuti, B. C. K., \& Stasi, A. (2019). How To Lead The Millennials: A Review Of 5 Major Leadership Theory Groups. Journal of Leadership in Organizations, 1(2), 96-111.

Pyöriä, P., Ojala, S., Saari, T., \& Järvinen, K. (2017). The Millennial Generation: A New Breed of Labour? SAGE Open, 1-14. https://doi.org/10.1177/2158244017697158
Ramayah, T., Ahmad, N. H., \& Hong, T. S. (2012). An Assessment of E-training Effectiveness in Multinational Companies in Malaysia. Journal of Educational Technology \& Society, $15(2)$.

Razak, R. A., Yusop, F. D., Perumal, Y., \& Chukumaran, S. R. (2015). The Developmental Process of Managing Virtual Training for Teachers. International Journal of Information and Education Technology, 5(8). https:/doi.org/10.7763/ IJIET.2015.V5.574

Schultz, R., Schwepker, C. H., \& Good, D. J. (2012). Generational research in the sales arena. Innovative Marketing, 8(1), $8-14$.

Shafini, N., Said, M., Fariana, S., Mori, C., Bidrul, S. A., Rapidah, S., \& Ali, O. (2016). The Relationship between Workplace Conflict and Job Performance : A Study of Staff in Terengganu Higher Learning Institution. Journal of Applied Environmental and Biological Sciences, 6(3S), 27-32.

Siagian, S. P. (2014). Human Resources Management. Jakarta, Indonesia: Bumi Aksara.

Smith, T. J., \& Nichols, T. (2015). Understanding the Millennial Generation. Journal of Business Diversity, 15(1), 39-47.

Sopiah, S., Kurniawan, D. T., Nora, E., \& Narmaditya, B. S. (2020). Does Talent Management Affect Employee Performance?: The Moderating Role of Work Engagement. Journal of Asian Finance, Economics and Business, 7(7), 335-341. https://doi. org/10.13106/jafeb.2020.vol7.no7.335

Valenti, A. (2019). Leadership Preferences of The Millennial Generation. Journal of Business Diversity, 19(1). https://doi. org/10.33423/jbd.v19i1.1357

Wolor, W., Kurnianti, D., Zahra, S. F., \& Martono, S. (2020). The Importance of Work-Life Balance on Employee Performance Millennial Generation in Indonesia. Journal of Critical Reviews, 7(9), 1103-1108. https://doi.org/http://dx.doi.org/10.31838/ jcr.07.09.203

Yamin, S. (2014). Lisrel Data Confidential Secrets. Jakarta, Indonesia: Mitra Wacana Media.

Yigit, S., \& Aksay, K. (2015). A Comparison between Generation $\mathrm{X}$ and Generation $\mathrm{Y}$ in Terms of Individual Innovativeness Behavior: The Case of Turkish Health Professionals. International Journal of Business Administration, 6(2). https:// doi.org/10.5430/ijba.v6n2p106 